\title{
AN IMPLICATION STUDY OF SOCIAL MEDIA LITERACY AT SCHOOL
}

\author{
Meliana Zhong \\ London School of Public Relations, Jakarta, Indonesia \\ melianazhong@gmail.com
}

\begin{abstract}
Abstrack
Internet has become a familiar instrument for the school aged children in Indonesia. The use of social media platforms - has changed the way of communication. In recent years, many students are drawn to social networking sites. This trend has caused the increasing reports of cyberbullying and potential cyber threats. The study took a qualitative approach and used the perimeter of the focus group discussion among 9-12 years old children in an international school in Jakarta. The thematic analysis grounded from observations, interviews and document reviews. The objective of the study is to seek the implication for schools to stand for a policy to promote constructive and safe school environment through social media literacy. It will deal with the aspects to empower students to understand that filtering and evaluating information are fundamental in daily internet browsing as well as understanding about cyberbullying and its consequences. The study concluded an implication towards the needs for schools to have a guideline for social media using among students. The guideline may serve as social media literacy to be implemented along with the digital literacy taught at schools, in expectance that students may become the responsible and ethical users of social media and technology.
\end{abstract}

Keywords: social media, social media literacy, cyberbullying, cyber threats

\begin{abstract}
Abstrak
Internet telah menjadi instrumen yang lazim bagi anak-anak usia sekolah di Indonesia. Penggunaan platform jejaring sosial telah mengubah cara berkomunikasi. Beberapa tahun belakangan ini, banyak pelajar tertarik kepada situs jejaring sosial. Kencederungan ini telah mengakibatkan peningkatan laporan kasus cyberbullying dan potensi ancaman dunia maya. Penelitian ini menggunakan pendekatan kualitatif dengan perimeter kelompok diskusi terfokus di antara anak-anak usia 9-12 tahun di suatu sekolah international di Jakarta. Analisa tematis didasarkan melalui observasi, wawancara dan tinjauan dokumen. Penelitian ini bertujuan memberikan implikasi kepada sekolah untuk membuat kebijakan yang membudayakan lingkungan sekolah yang konstruktif dan aman melalui literasi jejaring sosial. Aspek yang diharapkan adalah agar para pelajar mengerti pentingnya menyaring dan mengevaluasi informasi dalam penggunaan internet dan juga memahami cyberbullying termasuk akibat-akibat yang ditimbulkan. Kesimpulan dari penelitian ini adalah perlu adanya implikasi dari sekolah untuk menerapkan panduan dalam penggunaan media sosial bagi pelajar-pelajar. Panduan ini dapat disajikan dalam literasi media sosial yang dalam implementasinya berjalan seiiring dengan pengajaran literasi digital di sekolah yang diharapkan mampu menghasilkan pelajar-pelajar pengguna jejaring sosial dan teknologi yang etis dan bertanggung jawab.
\end{abstract}

Kata kunci: jejaring sosial, literasi jejaring sosial, cyberbullying, ancaman cyber

\section{INTRODUCTION}

Today digitalization era has provided indefinite access to technologies. According to Buckingham (2007:45) "Information and Communication Technology (ICT) has spread hastily in this digital era and influenced the way people live. Media such as computer and internet has become the dominants instruments in learning."

Hootsuite (We Are Social, 2019) - a content 
management website service providing the service of online media connected to several social media platforms, such as Facebook, Youtube, Facebook Messenger, Instagram, WeChat, Tiktok, Weibo, Twitter, LinkedIn, Snapchat and many others, indicated that there are about 4.388 billion internet users in the world or as many as $57 \%$ of the total population.

In Indonesia, Hootsuite (We Are Social, 2019) statically reported that the internet users in 2019 are around 150 million or as many as $56 \%$ of the total population. The same numbers are compatible with the active users of social media. It was about $15 \%$ increment from the total active users of social media reported in 2018. The site also revealed the average time people spent in accessing the internet, which is 8 hours and 36 minutes a day while the average time spent in using social media through any device is 3 hours and 26 minutes.

The easy and increase access to technologies and internet somehow has transformed the way people communicate. At the present time, social media has become the major basis for communication among people both in private and professional lives. The hasty dispersion of internet and the vast increasing numbers of social media users allow people to stay updated with the latest information, learning and communicating without having to travel.

"Social media is the unifying term for these "new digital media phenomena [...] in which ordinary users (i.e. not only media professionals) can communicate with each other and create and share content with others online through their personal networked computers and digital mobile devices" (Bechmann and Lomborg, 2013:767).

The use of social media has also gone through extensively among students. Why social media has now become a trend among students? Prakoso, Yuliati and Anggreni (2017:192) affirmed "social media is an unpaid media and people do not need to have any special skills in programming to use it. Ease in making social media account, the existence of self in following the lifestyle as well as their peers easily obtain information to encourage people to create social media accounts."

Undoubtedly, the positive outcomes of social media have enhanced these children in their pursuit for knowledge. Collin, Rahilly, Richardson and Third (2011:14) stated "evaluations of e-learning strategies have found social networking site platforms allow the extension of learning discussion outside the formal classroom setting, therefore promoting deeper learning as young people do not only engage with the material for longer but are more likely to relate it and incorporate it into their everyday lives."

These young people, are the most exposed to the advanced of technology and social media in this digitalization era, but are they aware of the threats behind the use of technology mitigation? Are they equipped with the proper proficiency to be the ethical and responsible users of social technologies?

The enormous growth in internet accessibility also brought a societal setback that requires attention to be comprehended. Livingstone (2003:13) stated that "almost anyone can produce and disseminate internet contents, with fewer - and very different kinds of - filters, the basis of critical literacy must alter, while teaching users to question the authority, objectivity or quality of mediated knowledge becomes ever more crucial."

Unlike traditional bullying, cyberbullying may be more difficult to address. Bhatt, Chang and Linscott (2010:37) mentioned "there is a power differential between cyberbully and target exists because the cyberbully has the power to hurt, shame, victimize or harass the target. The power may come from information that could be embarrassing or humiliating for the target if it is shared with others."

According to the statistics from the National Crime Prevention Council's 2010 Cyberbullying Prevention Study (2010), the impacts of cyberbullying are: Emotional (becomes withdrawn or shy, shows signs of 
depression, is extremely moody or agitated, is anxious or overly stressed out and shows signs of aggressive behavior), Social/ Behavioral (suddenly stops using the computer, changes eating or sleeping habits, no longer wants to participate in activities once enjoys, hurt self, attempts to threaten suicide, and suddenly changes friends), Academic (doesn't want to go to school, gets into trouble at school, skips school, loses interest in school, drops in grades).

There is some substantiation that these risky potentials of social media have been acknowledged and initially taken steps to minimize the threats (Hinduja \& Patchin, 2008; Kumar \& Somani, 2018). Palfrey (2008:7) indicated that "risky potentials online are not radically different in nature or scope than the risks minors have long faced offline, and minors who are most at risk in the offline world continue to be most at risk online."

The main objective of this study is to examine an urge of awareness to social media literacy as an implication measure to shield the young learners from the risky potential in online world. Previous studies have researched about the cyber threats and security risks of social networking sites (Kumar \& Somani, 2018) as well as indicated it as the major grounds for cyberbullying (Bauman, 2009; Gonzales, 2014). Other studies highlighted the importance of media literacy at school influenced by the digital environment (Buckingham, 2007; Pérez Escoda, 2014; Zhang \& Zhu, 2016).

However, instead of a larger scale of digital literacy, this study will concentrate on the mitigation of social media literacy to reprise cyberbullying and potential risks of social networking sites - the privacy threats and mitigation risks, distinguishing falsify information online and addiction to online games, particularly among the students of age 9-12 years old.

The interchanged media representation has changed the way children perceive information as well - for example, children learn to access the latest news through engaging to particular websites. There is an obvious shifting from the traditional literacy to the media literacy experienced by the children. Escoda (2013: 4748) argued that "traditional literacy at schools presents a lack of content, a lack of skills concerned with managing, processing and assuming the amount of information generated every day on the internet."

Through social media, children are able to engage and interact with larger social world. The term social media refers to "the sites and services that emerged during the early 2000s, including social network sites, video sharing sites, blogging and microblogging platforms, and related tools that allow participants to create and share their own content" (Boyd, 2014).

Nowadays, children must seize their affordances as competent users of social media networking sites. Livingstone (2014:3) refined "this includes understanding how the social networking sites encode user privacy or safety, how they represent friends as contacts and affiliation through likes, and how they embed advertising and sponsorship."

However, there are cyber threats glimpsing behind the social media using, from the cyberbullying to the online risks mitigation. Livingstone, Stoilova and Kelly (2016) refers "cyberbullying occurs in places little monitored by adults by text messages on a personal mobile phone, in multiplayer online games, on social networking sites." The other cyber threats, as described by Mushayt (2013) are termed as malwares, phising, trojan horses, leaking of confidential information, condensed electronic links and impersonation. On the other hand, while social media gives many positive impacts to the students, it also provides negative sides to be weighed. Gorhe (2019) indicated "when a student gets too involved in the use of social media, it affects his overall academic performance."

To understand how children encompass the use of social networking sites into their daily reality, a drawing to the Media Ecology 
Theory best describes the social impact of the said technology and communication. McLuhan (1964) noted "the society became reliant on social media - such as social networking sites - for many reasons such as efficiency and ease. Technology has progressed overtime - forcing people to adapt - and social networking sites are no different." Parameswaran (2008:2) defined media ecology theory as" the study of how the media and the processes of communication affect human perception, understanding, feeling and value."

While Media Ecology Theory hubs on the idea that technology - including social media, have influenced the value of lives in this digitalization era, it is also said that the growth of the phenomenon lies widely on the children's social development. Additional to this, it is generally known that children and young teenagers are significantly influenced by peer relations and self-identity, which to date is often channeled through social networking sites. Livingstone (2014:3) stated "Older children - up to around 12 years old - are developing the cognitive maturity by which to recognise that many portrayals, even of real people, are not "real" accounts of the world but may be fictional, playful, persuasive or misleading." The study, therefore, put into concerns that children at such ages might not be fully perceived what the see on social media as truthful experience.

This study conceptualize the behavior in using social media among the students of aged $9-12$ years old, regarding the interactions opportunity in using social media and the social norms of trust, reputation and social identity (Livingstone, 2014; Litt \& Hargittai, 2014). By understanding the behavior of interaction among students that has interchanged along with the initiation of social media, the approach towards the literacy in comprehending the skills may be seen in the features of social media literacy. Livingstone (2014:3) conceived "social media literacy in encompassing the tasks of decoding, evaluating and creating communication in relation to media qua presentation (text, image, platform, device, etc.) and qua social interaction (relationships, networks, privacy, anonymity, etc.), since these are integrated in the very nature and use of social networking sites (SNSs)."

The study further seeks the findings using constructivism paradigm. An understanding towards the socio-psychological act behind the use of social media was also taken as an empirical consideration in order to examine the engagement of students in mitigating cyberbullying and cyber threats of social networking sites, along with the implication of social media literacy in reprising the potential cyber harms.

\section{METHODOLOGY}

The study took a qualitative approach with the a pilot phase study was initiated in 2019 at Bina Tunas Bangsa School, Jakarta, taken from the students of Primary 5-Primary 6 or aged group of 9-12 years old, with the total of 204 students. The initiation was conducted through a school assembly in which the students were asked about the engagement behavior in social media.

The data collection was from the Focus Group Discussion (FGD) and documentation (Firman, 2018). The Focus Group discussion was taken from Group I consisted of Primary 5 students while Group II was represented by Primary 6 students. The open-ended topic guide was designed to attain the students' perception regarding their online activities including the awareness of the potential risks in social networking sites and cyberbullying. The documentation was taken from internal official database on cases reported regarding social media misconduct happened in Bina Tunas Bangsa School within the year 2017-2019.

The perimeter of the study concentrates on the focus group of 9-12 years old or Primary 5 and Primary 6 students is based on the suggestion that the children at those age are conceived to 
be in middle childhood (upper end of Primary School years) in Indonesia. Indisputable, those aged children are equipped with the access to technologies and smart phones but not with the knowledge of potential risks behind it.

The data validation of the study was based on suggestion of Gibson and O'Connor (2003) which noted "Validation does not belong in some separate stage of the investigation, but instead as an ongoing principle throughout the entire research process." A reflection towards the purpose of the research, that is implying the social media literacy at school and also an exhaustive and conceptually congruent (Merriam, 1998) were drawn into the narrative and thematic analysis of the study was drawn based on the FGD and the documents review into four categories: (1) What is Cyberbullying? (2)When is a Stranger Becoming a Danger? (3) How to Tell the Real and the Fake? and (4) When is Enough Will Be Enough?

\section{RESULT AND DISCUSSION}

Europen Schoolnet Social Media Literacy for Change (2019) uttered the following risky potentials of social media towards students: exclusion or social pressure; exposure to online risks such as bullying, sextortion, radicalization and fake or illegal content; exposure to privacy threats and harmful or misleading commercial communication: and copyright infringements.

The nature of social networking sites allows the broad and extensive flow of information. One of the perilous consequences it causes is the phenomenon of cyberbullying. Cyberbullying is indicated as the major cause of the rapid use of internet as social interaction tools. Cyberbullying has been defined as "willful and repeated harm inflicted through the use of computers, cell phones, and other electronic devices." (Hinduja \& Patchin, 2009).

When asked about the use of social media, the aged 9-12 years old children gained an understanding of the following most renowned platforms known by them: Instagram, Facebook,
Facebook Messenger, Line, Youtube, Whatsapp and Email. The children admitted that they have registered in at least two of the mentioned social networking sites, while a few of them mentioned that they still shared the account with their parents. To the surprise, none of them was aware that the social networking sites have age restrictions:

The figure below described the age restriction applied in using social media. Facebook, Instagram, Youtube and Twitter restricted the users to be at least 13 years above while Whatsapp urged the users to be at least 16 years.

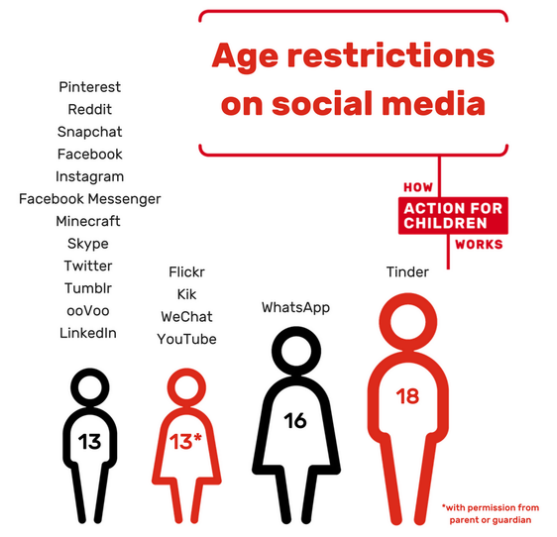

Figure 1. Age Restriction on Social Media

Retrived from https://learningrenaissance. wordpress.com/2017/02/09/age-restrictions-onsocial-media-sid2017/

The children were eager to discuss about the social networking ambiance including the potential risks behind it. They had initial awareness regarding cyberbullying, stranger danger, hoax and addiction, though most of them mentioned the understanding they gained were from the parents information or the reading on the mass media and workshops given at school.

There were many possible themes drawn to be analyzed from the focus group discussions; nevertheless, taking into account the children familiarization to the renowned social media networking sites and to make it parallel to the intended awareness and development of social media literacy, the study will describe the findings into four coherent courses: what 
is cyberbullying, when is a danger becoming a danger, how to tell the real and the fake news and when is enough will be enough.

\section{What is Cyberbullying?}

When being asked the definition of cyberbullying, the focus group aged 9-12 years old mostly answered by underlining cyberbullying as an act of violence conducted through online media with the purpose to hurt someone. In fact, the designation of cyberbullying goes beyond the understanding of the children. Consider this excerpt by an 11 year old girl:

"My friend took a picture of one of our classmates while she was changing in the changing room during a school excursion. She posted it on the whatsapp groups and everyone was laughing about it. I know it was a bad thing but it was just funny. Then the teacher found it out and he asked us to delete the picture. He was angry but it is not like we were doing violence or saying bad things about our friend. It was just for fun. She wasn't even upset her picture was taken. Why made so much hassle about it?"

An apparent fact, the girl who took the picture of her friend while she was changing was known to be a compliant student with above average grades in the classroom. From the way the incident was described, there was an implication that the behavior was generally accepted as there was no violence or hurting intention implied, instead it was merely for peers entertaining. But in the culture of communication, the Whatsapp affordances for disseminating messages had been wrongly utilized. Furthermore, it was then discerned that the girl whose picture was taken did not make any confrontation due to the peer pressure, fear of being excluded from the group that caused her to be silent.

Among 9-12 years old children, there was no distinct understanding of cyberbullying. A 12 year old boy was suddenly exited from the
Whatsapp group by his peers, not aware this as an act of exclusion, a form of cyberbullying.

The findings also reported that some of the focus group children, aged 9-12 years old experienced hurtful or fuming messages through their Instagram. The said social media platform provides a Direct Message (DM) feature which enables the recipient to receive private messages from anyone. This has made it possible for the cyberbullies to disseminate vicious messages and hid behind its anonymity.

To most, the focus group discussion revealed that they did not report the occurrence to their parents and teachers at school for fear of not being allowed to use the gadgets anymore.

\section{When is a Stranger Becoming a Danger?}

With the explosive public features social media networking sites provide, access to information has become an easy task. This puts the children into the vulnerable target of deception from outside. Yet at this age of 9-12 years old, the children distinguished cyber threats as clearly distinct. They were seemingly starting to have positive ambiguities towards the distortion, such as not sharing passwords to anyone, but the apparent comprehension about the "stranger danger" were distorted offline rather than online. A Primary 5 boy, aged 11, depicted his perception about stranger danger online:

"My parents told me about stranger danger - it is like, you shouldn't talk to a stranger or follow him anywhere because you don't know him. Information I posted on Facebook? Well, they are just about the school where I study, my birthday - because I like it when my friends greet me birthday online, my hometown.

The internet is a public space. Every picture, information or video posted online can be made accessible by the audience globally; many of them are strangers that are not in the list of social online friends. What seems to be missing in the perspective of students is the stranger is more dangerous online for it has the anonymity. 
Most of the children admitted that they had the public setting for their social media account, such as Instagram, for having a big number of followers is acknowledged as a pride.

"Now I have more than 200 followers on my Instagram. I practically set my account for public so anyone can follow me. I don't see the reason why I shouldn't let people follow my postings, even though they are people I don't know. I mean, it should be okay because it is not like I'm going to give them my password. I think it is very common because people make friends through online nowadays." (A 12 years old girl)

The description above concluded how the children do not sense any potential harm from stranger danger. By welcoming any stranger to be the circle of friends on social media, it means opening the door for potential risks that may follow.

\section{How to Tell the Real and the Fake?}

The youngsters in this digitalization era may be known as "digital natives, the native speakers of the digital language of computers, video games and the internet" (Prensky, 2001), but among the 9-12 years old, there is a lack of profoundly experience in using social networking sites. Many of these children are not attentive to the conception of news or information they read from social media.

The children were flashed several pictures of the occurrence, such as the impact the nuclear did the environment, the cropped or edited photographs and the latest power outage happened in Jakarta on August 2019. The reaction from the students was essentially in acceptance to the pictures shown, almost without questioning to the validity of deliverance.

It is implicit that the focus aged group 9-12 years old do not have a clear conception of fakery or falsify information online. They are still not equipped with what according to Better Internet Campaign - Media Literacy Council (2019) the C-S-I when evaluating information online:

Credibility: Does the content have various perspectives or just one point of view? Is it an opinion?

Source: What is their reputation? Are they trustworthy? Can the information be independently verified? The publisher, e.g. newspaper, website, is one source. The author is another source.

Intent: What is the agenda of the source? What are they hoping to achieve by publishing the information?

Things posted online can be used as a tool to attack and causes harm. It is important for the students to build barriers in digital world and discern to filter which to be shared and which is to be kept confidential.

\section{When is Enough will be Enough?}

Another transformation of social networking sites comes in the form of online games.

Most of today's online games, known as Massively-Multiplayer Online Role-Playing Games (MMORPG) provide the feature in which players may communicate among gamers. Jia, Shen, Bovenkamp, Iosup, Kuipers and Eperma (2015) stated that "the online gaming experiences have attracted hundreds of millions of people world-wide who communicate, interact and socialize with each other through gaming"

Online games, as one of the consequences of the rise of the internet, provide the children with pleasure and social environment. It is undeniable that children nowadays are attached with their computers and gadgets - sinking themselves in the world of online gaming. Consider a depiction of online gaming by 11 years old boy:

"The best weekend for me is if I may stay at home, no classes to attend and no homework, so I may play online games the whole day. I am not allowed by my parents to play games during weekdays, so weekend is the only time I may use my Ipad and play online games. I meet 
people from another cities and countries in my game. We talk, but mostly about the game strategies only."

The heartbreaking fact check: In previous time, parents had difficulty to ask their children to stay at home as they preferred to loiter around and play outside. The current phenomenon signifies children do not like to have a direct and physical interaction; rather they opt to face the screen, play interactive games and have social communications online.

Implicit in their answers appear to be a formation of entertainment found in online gaming but the boundaries towards the potential risks of online gaming is beyond the embracement. The children recognized the initial risks in online gaming, such as addition, results in lower grade performance and scammers - but the understanding was seemingly preoccupied by the entertaining pleasure it offers. The children are not conscious of the threats, as suggested by Childnet (2017): the risks of exposure to inappropriate materials, bullying or abuse, personal information made public and commercialism or invasion of privacy by aggressive advertising and marketing schemes.

While there is no specific time that coherently suggests how much time a child should be engaged in online gaming, the portray of children associated with online gaming addiction has become a discern in the society. A question was addressed to students, asking how much time they thought would be appropriate to spend in online games. To this, the responses varied from "until I am tired or sleepy" to "there will never be enough."

\section{DISCUSSION}

The competencies of digital and media literacy are among core competencies for students as "digital citizenships, defined as the ability to use technology safely, responsibly, critically, productively, and civically" (Farmer, 2010). Those competencies allow them to access to contextual information, knowledge construction and the holistic of digital learning. Most children generally have an initial knowledge about social media but the potential risks entailing it seem to be distinct for them. The youngest group of students (Group I) had the minimal knowledge about risks behind the social media and generally reliant on the parents for safety. The students tended to be unsure about trustworthiness and could not distinguish the interactions between online and offline.

The study found that the age restriction for the users of social media is unaware by the children. The Children's Online Privacy Protection Act (COPPA, 1998) protected every child under the age of 13 . The Act required that all operators of websites and online services to provide a notice and obtain permission from a child's parents before collecting any personal information - such as name, address, phone number and screen name - from that child.

The online opportunities also open widely for cyberbullying. Many researchers have concluded cyberbullying as the cause of social media existence (Li, 2007; Bauman, 2009; Bhat, Chang \& Linscott, 2010; Gonzales, 2014). Apparently, many students could not distinguish the clear line of cyberbullying and the forms. The online multiplayer games also provide opportunity for cyberbullying that should be addressed. It is very important to sustain the positive school environment that is free from any form of bullying. Willard (2006) suggested that "school should be vigilant about incorporating cyberbullying and online safety into their safe schools agenda."

Evidently, there is an emergent momentum to instill the awareness of social media literacy as the integration of digital and media literacy. While digital literacy is commonly adopted in the pedagogy setting of school curriculum, social media literacy is still seen as the liability of home considering social media activities mostly occur outside school environment. Thus, for the purpose of developing and promoting a 
positive and safe school environment as well as preparing the students as the digital citizenships (Farmer, 2010), school has an urgency to design a social media literacy that is expected to provide information and knowledge about cyberbullying as well as give insight to the students how to make responsible choices and access information in social networking sites.

\section{CONCLUSION}

The outgrowing of social media is something that cannot be impeded; rather it should be seen as transformation of traditional communication in this digitalization era that needs to be embraced. The characteristics commenced by the social media networking sites require the users to possess the skills to evaluate the content and build the consciousness to be the ethical and accountable users. The children's engagement in using social media has emerged to put themselves into potential cyber risks; nevertheless, the children's impulse to take the risks and violate the boundaries comes from the desire to be independent from the parents and to attribute identity from the peers networking while formulate their own roles in the social world. Social media literacy should begin at the underpinning from the house family, educators and concerned citizens, seeing that social media has played a fundamental act as a teacher from where children also seek for knowledge and information as well as extending their social networking. Schools, as the basis for formal education - have a power to regulate the social media literacy for the students, of course in the expectance that the students will establish themselves as the literate digital media users with the acceptable culture norms. The children are best to be oriented on the benefits of social media while at the same time, have a holistic knowledge about the consequences and the potential risks, from cyberbullying, privacy threats, impersonation, dissemination of fake news and offensive contents, addiction that may lead to academic regression. The social media literacy may serve as a guideline for the children to make a responsible judgment and build critical evaluation skills that not only will help them incorporate their learning within this digitalization era.

\section{REFERENCES}

Bauman, S. (2009). Cyberbullying: a Virtual Menace. Cyberbullying - A menace.

Bechmann A and Lomborg S (2013) Mapping actor roles in social media: Different perspectives on value creation in theories of user participation. New Media \& Society 15(5): 765-781.

Better Internet Campaign 2019. (n.d.). Retrieved from https://www.betterinternet.sg/

Bhat, C. S., Chang, S., \& Linscott, J. A. (2010). Addressing Cyberbullying as a Media Literacy Issue. New Horizons in Education, 58(3), 34-43.

Boyd, d. (2014). It's complicated: The social lives of networked teens. New Haven, CT: Yale University Press.

Buckingham, D. (2007). Digital Media Literacies: Rethinking Media Education in the Age of the Internet. Research in Comparative and International Education,2(1), 43-55. doi:10.2304/ rcie.2007.2.1.43

Childnet. (2017, June 22). Online Gaming: An introduction for parents and carers. Retrieved from https://www.childnet. com/resources/online-gaming-anintroduction-for-parents

Children's Online Privacy Protection Rule ("COPPA"). (2018, October 04). Retrieved from https://www.ftc. gov/enforcement/rules/rulemakingregulatory-reform-proceedings / childrens-online-privacy-protectionrule

Collin, P., Rahilly, K., Richardson, I., \& Third, A. (2011). The benefits of social networking services: Literature review. Melbourne: Cooperative Research 
Centre for Young People, Technology and Wellbeing.

Davis, J. (2001). CYBERBULLYING SPOTTING THE SIGNS. Retrieved August 8, 2019, from https://www. ncpc.org/wp-content/uploads/2017/11/ N C P C _ C y b e r b u 11 y i n g SpottingTheSigns.pdf

Farmer, L. S. (2010). Teaching Digital Citizenship. Department of Advanced Studies in Education and Counseling. California State of University.

Firman, F. -. (2018). Penelitian Kualitatif Dan Kuantitatif. doi:10.31227/osf.io/4nq5e

Gibson, N., \& O'Connor, H. (2003). A StepBy-Step Guide to Qualitative Data Analysis. A Journal of Aboriginal and Indigenous Community Health.

Global Digital Report 2019. (n.d.). Retrieved from https://wearesocial.com/globaldigital-report-2019

Gonzales, R. H. (2014). Social Media as a Channel and its Implications on Cyber Bullying. Presented at the DLSU Research Congress 2014,LCCS-I-009.

Gorhe, M. (2019). Impact Of Social Media On Academic Performance Of Students. Social Media As A Tool -Technical Report. University of San Francisco. doi: 10.13140/ RG.2.2.21427.27687

Hinduja, S., \& Patchin, J. W. (2008). Personal information of adolescents on the Internet: A quantitative content analysis of MySpace. Journal of Adolescence,31(1), 125-146. doi:10.1016/j.adolescence.2007.05.004

Hinduja, S., \& Patchin, J. W. (2009). Bullying beyond the schoolyard: Preventing and responding to cyberbullying. Thousand Oaks, CA: Sage Publications (Corwin Press).

Jia, A. L., Shen, S., Bovenkamp, R. V., Iosup, A., Kuipers, F., \& Epema, D. H. (2015). Socializing by Gaming. ACM
Transactions on Knowledge

Discovery from Data,10(2), 1-29. doi:10.1145/2736698

Kumar, S., Dr, \& Somani, V. (april 2018). Social Media Security Risks, Cyber Threats And Risks Prevention And Mitigation Techniques. International Journal of Advance Research in Computer Science and Management,4(4), 125-129.

Li, Q. (2007). Bullying in the new playground: Research into cyberbullying and cyber victimisation. Australasian Journal of Educational Technology,23(4). doi:10.14742/ajet.1245

Litt, E., \& Hargittai, E. (2014). Smile, snap, and share? A nuanced approach to privacy and online photo-sharing. Poetics, 42, 1-21. doi:10.1016/j.poetic.2013.10.002

Livingstone, S. (2014). Developing social media literacy: How children learn to interpret risky opportunities on social network sites. Communications, 39(3). doi: 10.1515/commun-2014-0113

Livingstone, S., Stoilova, M., \& Kelly, A. (2016). Cyberbullying: Incidence, trends and consequences. In Ending the torment: Tackling bullying from the schoolyard to cyberspace (pp. 115-120). New York: United Nations Publications.

McLuhan, M. (1964). Understanding media; the extensions of man (1st ed ed.). New York: McGraw Hill.

Merriam, S. B. (1998). Qualitative research and case study applications in education. San Franciso: Jossey-Bass.

Mushayt, O. S. A. (2013). Threats and Anti-threats Strategies for Social Networking Websites. International Journal of Computer Networks \& Communications, 5(4), 53-61. doi: 10.5121/ijenc.2013.5405

Palfrey, J., Sacco, D. boyd, d.. DeBonis, L. (2008) Enhancing Child Safety \& Online Technologies: Final Report 
of the Internet Safety Technical Task Force, Harvard University, Berkman.

Parameswaran, K. (2008). Interactive Television Programmes: A Study in Media Ecology. Language In India, 8. Pérez Escoda, A. (2014). Media literacy in primary school: new challenges in the digital age. Revista Teoría de la Educación: Educación y Cultura en la Sociedad de la Información. 15(1), 4369

Pérez Escoda, A. (2014). Media literacy in primary school: new challenges in the digital age. Revista Teoría de la Educación: Educación y Cultura en la Sociedad de la Información. 15(1), 4369

Prakoso, S. G., Yuliarti, M. S., \& Anggreni, L. S. (2017). The Importance of Social Media Literacy for Students in Globalization Age. KnE Social Sciences,2(4), 191. doi:10.18502/kss.v2i4.886

Prensky, M. (2001). Digital Natives, Digital Immigrants. On the Horizon (MCB University Press), 9(5).

Social Media Literacy for Change. (n.d.). Retrieved July 11, 2019, from https:// www.europeanschoolnetacademy.eu/ web/social-media-literacy-for-change

Willard, N.E. (2006). Cyber bullying and cyberthreats: Responding to the challenge of online social cruelty, threats and distress (2nd ed.). Eugene, OR: Center for Safe and Responsible Internet Use (CSIRU).

Zhang, H., \& Zhu, C. (2016). A Study of Digital Media Literacy of the 5th and 6th Grade Primary Students in Beijing. The AsiaPacific Education Researcher,25(4), 579-592. doi:10.1007/s40299-016$0285-2$ 